\title{
NORMA-NORMA HUKUM HAK ASASI MANUSIA DALAM AL-QURAN: STUDI KRITIS ATAS TAFSIR AL-QURAN SURAT AL-NISÂ' AYAT 135
}

\author{
Deni Kamaludin Yusup \\ Fakultas Syari'ah dan Hukum UIN Sunan Gunung Djati Bandung \\ Email:dk_yusup@yahoo.com
}

\begin{abstract}
This paper is simply explaining on the legal norms of human rights in the Quran through critical study on the Quranic interpretation Surah al-Nisâ' verse 135. As the primary source of Islamic law, the Quran is believed covered the various verses which are relevant with the legal norms of human rights. Moreover the guarantee of human rights and its consideration in the Quran has been presently existed more than the idea of human rights in Western world. In addition, the crucial proble here is not talking about accepting or rejecting human rights within the Quran, but many scholars find the difficulties on understanding human rights in the Quran more than accepting it as the Holy Book and the way of life for human beings.
\end{abstract}

\begin{abstract}
Abstrak
Tulisan ini menjelaskan secara ringkas tentang norma-norma hukum HAM dalam alQuran melalui pendekatan studi kritis atas tafsir al-Quran Surat al-Nisâ' ayat 135 . Sebagai sumber utama hukum Islam, al-Quran diyakini telah memuat ayat-ayat hukum yang memiliki relevansi dengan norma-norma hukum HAM. Bahkan pengakuan terhadap HAM dalam al-Quran sudah lebih dulu ada jauh sebelum gagasan HAM muncul di dunia Barat. Persoalan paling krusial adalah bukan menerima atau menolak HAM dalam al-Quran, tapi kebanyakan pemikir cenderung kesulitan memahami HAM dalam al-Quran lebih dari sekedar menolak al-Quran itu sendiri sebagai Wahyu Allah dan pedoman hidup manusia.
\end{abstract}

Kata Kunci:

Ayat Hukum, Norma Hukum, Metode Tafsir, Hak Asasi Manusia

\section{A. Pendahuluan}

Hak Asasi Manusia (HAM) menjadi topik pembicaraan yang selalu aktual dan menarik untuk dibahas dan dikaji. la menjadi aktual karena sering dilecehkan dalam sejarah umat manusia sejak awal hingga kurun waktu kini. Hal ini disebabkan banyaknya kejadian yang berhubungan dengan masalah tersebut. Oleh karena itu, suatu peristiwa yang terjadi dalam sebuah lembaga, institusi, atau bahkan dalam sebuah negara yang dipandang melakukan perbuatan melanggar Hak Asasi Manusia (HAM) pasti akan menimbulkan protes atau keprihatinan pihak-pihak lain.

Paling tidak ada dua asumsi dasar yang mengilhami penulis untuk mengangkat masalah ini. Pertama, permasalahan ini muncul karena konsep tentang HAM dipandang belum jelas, baik dari sisi esensi maupun eksis- tensinya. Akibatnya, terjadi banyak interpretasi baik pada ranah politik maupun hukum, yang sekaligus dapat mempengaruhi pengakuan bagi diterima atau ditolaknya HAM. Kedua, al-Quran diyakini telah memuat semua norma-norma hukum yang erat kaitannya dengan HAM, berisikan hak-hak dan kewajiban-kewajiban manusia yang dilahirkan sebagai mukallaf, serta tersebar lebih dari sekitar 287 ayat yang semuanya berkaitan dengan HAM. Misalnya, ayat-ayat tentang manusia, pembunuhan, kebebasan, keadilan, persamaan, dan kesejahteraan.

Atas dasar itu, sangat penting mengembangkan konsep-konsep mutakhir yang erat kaitannya dengan aktualisasi norma-norma hukum HAM dalam al-Quran. Hal ini dapat ditemukan secara utuh dan komprehensif dalam al-Quran, terlebih jika dikaji melalui 
pendekatan tafsir tematik dan kontekstual sesuai dengan tujuan kepentingan ilmiah dan akademis. Dengan demikian dapat memberikan sumbangan pemikiran bagi pengembangan ilmu hukum Islam yang dikombinasikan dengan tafsir al-Quran kekinian.

Berdasarkan asumsi-asumsi dasar yang dikemukakan di atas, masalah pokok yang dikaji dalam penelitian ini adalah bagaimana perumusan norma-norma hukum HAM dalam al-Quran, bagaimana hakikat dan eksistensi HAM dalam al-Quran, apa saja hak-hak dasar manusia dalam al-Quran, dan bagaimana mengaktualisasikan norma-norma hukum HAM dalam al-Quran ke dalam konteks keninian. Tulisan ini akan dikembangkan pemikiran secara eksploratif untuk menggali, merumuskan dan mengembangkan konsepkonsep baru tentang HAM melalui pendekatan tafsir ayat al-Quran.

\section{B. Kerangka Konseptual Studi Kritis Tafsir Al-Quran}

Untuk melakukan studi kritis terhadap ayar al-Quran bukanlah mengkritik atau menilai mengenai otentisitas dan originalitas ayat al-Quran, namun mengkaji lebih dalam berkenaan dengan topik suatu ayat, faktor yang menyebabkan ayat tersebut turun, hubungan dan relevansinya dengan ayat yang lain, serta makna hukum yang terkandung di dalam suatu ayat, dan aktualisasinya dengan kehidupan saat ini.

Langkah awal yang digunakan dalam tulisan ini adalah penulis ingin menggunakan corak studi kepustakaan (library research) dengan menggunakan ayat-ayat al-Quran sebagai data primer dan pendapat para ahli tafsir dalam berbagai kitab tafsir sebagai data sekunder. Analisis dan interpretasi dalam tulisan ini juga akan menggunakan pendekatan normatif-historis untuk meninjau ayatayat al-Quran dan hadits-hadits Nabi SAW yang diduga kuat mengandung ajaran-ajaran, prinsip-prinsip, dan wujud penjabaran norma-norma hukum HAM.

Adapun pendekatan historis digunakan untuk menyoroti perkembangan asal-usul dan pemikiran dari para pakar hukum secara metodologis tentang HAM. Sedangkan metode yang digunakan adalah metode tafsîr madlûî (tematik) yang banyak digunakan un- tuk mengetahui keserasian dan korelasi antara ayat-ayat dalam satu tema atau topik tertentu. Hal demikian dipandang dapat memudahkan bagi penulis untuk mengungkap makna-makna dan petunjuk al-Quran terhadap tema yang sedang dikaji.

Selanjutnya pada tahapan analisis pembahasan penulis juga menggunakan teknik analisis isi (content analysis), yaitu teknik analisis yang digunakan untuk mengkaji makna dan kandungan dari setiap ayat yang dibahas sehingga diperoleh pengetahuanpengetahuan qurani. Penggunaan teknik ini sangat dimungkinkan berdasarkan data-data deskriptif dan telaahnya yang bersifat kualitatif melalui korelasi antara ayat hukum dengan contoh obyek hukum yang sedang dianalisis.

Metode tafsir yang digunakan untuk menafsirkan QS. al-Nisâ' ayat 135 dalam tulisan ini adalah metode tafsîr mawdlûî̀. Metode Mawdlûîi (tematik) ialah membahas ayatayat al-Quran sesuai dengan tema atau judul yang telah ditetapkan. Semua ayat yang berkaitan, dihimpun. Kemudian dikahi secara mendalam dan tuntas dari berbagai aspek yang terkait dengannya seperti asbâb alnuzûl, kosa kata dan sebagainya. Semuanya dijelaskan secara rinci dan tuntas, serta didukung oleh dalil-dalil atau fakta yang dapat dipertanggungjawabkan secara ilmiah; baik argumen itu berasal dari al-Quran dan alHadits, maupun pemikiran rasional.

Sedangkan yang menjadi ciri utama metode ini ialah menonjolkan tema, judul atau topik pembahasan; sehingga tidak salah bila di katakan bahwa metode ini juga disebut metode "topikal". Jadi mufasir mencari tema-tema atau topik-topik yang ada si tengah masyarakat atau berasal dari alQuran itu sendiri, ataupun dari yang lain. Kemudian tema-tema yang sudah dipilih itu dikaji secara tuntas dan menyeluruh dari berbagai aspek, sesuai dengan kapasitas atau petunjuk yang termuat di dalam ayat-ayat yang ditafsirkan tersebut. Artinya penafsiran yang diberikan tak boleh jauh dari pemahaman ayat-ayat al-Quran, agar tidak terkesan penafsiran tersebut berangkat dari pemikiran atau terkaan belaka ( $a l-R a^{\prime} y$ alMahdlah). 
Sementara itu, 'Abdul Hay al-Famawî̀ seorang guru besar pada Fakultas Ushuluddin al-Azhar, dalam bukunya al-Bidâyah fî al-Tafsîr al-Mawdlûî mengemukakan secara rinci menjelaskan langkah-langkah yang hendak ditempuh untuk menerapkan metode Mawdlû́î. Langkah-langkah tersebut adalah:

1. Menetapkan masalah yang akan dibahas (topik);

2. Menghimpun ayat-ayat yang berkaitan dengan masalah tersebut;

3. Menyusun runtutan ayat sesuai dengan masa turunnya, disertai pengetahuan tentang asbâb al-nuzûl-nya;

4. Memahami korelasi ayat-ayat tersebut dalam surahnya masing-masing;

5. Menyusun pembahasan dalam kerangka yang sempurna (out-line);

6. Melengkapi pembahasan dengan haditshadits yang relevan dengan pokok bahasan; dan

7. Mempelajari ayat-ayat tersebut secara keseluruhan dengan jalan menghimpun ayat-ayatnya yang mempunyai pengertian yang sama, atau mengkompromikan antara lafazh yang 'âmm (umum) dan yang khas (khusus), muthlaq dan muqayyad (terikat), atau yang pada lahirnya dianggap bertentangan, sehingga kesemuanya bertemu dalam satu muara, tanpa perdebatan atau pemaksaan.

Selain metode Tafsîr Mawdlûî̂, M. Quraish Shihab juga menjelaskan metode tahlîli dan metode mawdlûîi. Namun begitu, dari beberapa tokoh analis Islam, kedua metode tersebut di samping mempunyai kelebihan disatu sisi, pada sisi yang lain mempunyai kelemahan-kelemahan. Metode tahlîli atau yang dinamai oleh Muhammad Bâqir al-Shadr sebagai metode tajzîî.

Walaupun sangat luas - karena cara menafsirkan ayat-ayat al-Quran dari berbagai segi - namun tidak menyelesaikan satu pokok bahasan, karena seringkali satu pokok bahasan diuraikan sisinya atau kelanjutannya, pada ayat lain. Pemikir al-Jazâir kontemporer, Mâlik bin Nabî, menilai bahwa upaya para ulama menafsirkan al-Quran de-

'Abdul Hay al-Famawî, al-Bidâyah fî al-Tafsîr alMaudlû'î(Kairo: al-Hadlarah al-'Arâbiyyah. 1977), hlm. 87. ngan metode tahlîili itu, tidak lain kecuali dalam rangka upaya mereka meletakkan dasar-dasar rasional bagi pemahaman akan kemukjizatan al-Quran.

Terlepas dari bernar tidaknya pendapat Malik tersebut, namun yang jelas kemukjizatan al-Quran tidak ditujukan kecuali kepada mereka yang tidak percaya. Hal ini dapat dibuktikan dengan cara memperhatikan rumusan definisi mukjizat di mana terkadang di dalamnya unsur tahaddî (tantangan), sedangkan seorang Muslim tidak perlu ditantang karena dengan keislamannya ia juga telah menerima. Bukti kedua dapat dilihat dari teks ayat-ayat yang berbicara tentang keluarbiasaan al-Quran yang dimulai dengan kalimat إنكنتمفىريب atau إنكنتمصدقين.

Kalau tujuan penggunaan metode tahlîli seperti yang diungkapkan Malik di atas, maka terlepas dari keberhasilan atau kegagalan mereka, yang jelas untuk masyarakat Muslim dewasa ini, paling tidak persoalan tersebut bukan lagi merupakan persoalan yang mendesak. Karenanya, untuk masa kini, pengembangan metode penafsiran menjadi amat dibutuhkan, apalagi jika kita sependapat dengan Bâqir al-Shadr - Ulama Syi'ah Irak itu - yang telah menilai bahwa metode tahlîli telah menghasilkan pandanganpandangan parsial serta kontradiktif dalam kehidupan umat Islam. ${ }^{2}$

Di samping itu, penting untuk ditambahkan di sini bahwa para penafsir yang menggunakan metode tahlîli tidak jarang hanya berusaha menemukan dalil atau lebih tepat dalih pembenaran pendapatnya dengan ayat-ayat al-Quran. Selain itu, terasa sekali bahwa metode ini tidak mampu memberi jawaban tuntas tentang persoalan-persoalan yang dihadapi sekaligus tidak banyak memberi pagar-pagar metodologis yang dapat mengurangi subjektivitas mufasirnya.

Kelemahan lain yang dirasakan dalam tafsir-tafsir yang menggunakan metode tahlîli dan yang masih perlu dicari penyebabnya - apakah pada diri kita atau metode mereka - adalah bahwa bahasa-bahasanya dirasakan sebagai "mengikat" generasi berikutnya. Hal ini mengacu kepada penafsiran persoalan-persoalan khusus yang mereka alami dalam masyarakat mereka, sehingga

2 Ibid. 
uraian yang bersifat teoritis dan umum itu mengesankan bahwa itulah pandangan alQuran untuk waktu dan tempat.

Sedang metode Mawdlû́îy yang mana mufasirnya berupaya menghimpun ayat-ayat al-Quran dari berbagai surat dan yang berkaitan dengan persoalan atau topik yang ditetapkan sebelumnya. Kemudian, penafsir membahas dan menganalisis kandungan ayat-ayat tersebut sehingga menjadi satu kesatuan yang utuh dan tidak terpisahkan satu sama lain.

Beberapa keistimewaan metode Mawdlû'îy antara lain: (1) Menghindari problem atau kelemahan metode lain; (2) Menafsir- kan ayat dengan ayat atau dengan hadits Nabi, satu cara terbaik dalam menafsirkan alQuran; (3) Kesimpulan yang dihasilkan mudah dipahami; dan (4) Metode ini juga memungkinkan seseorang untuk menolak anggapan adanya ayat-ayat yang bertentangan dalam al-Quran. la sekaligus dapat dijadikan bukti bahwa ayat-ayat al-Quran sejalan dengan perkembangan ilmu pengetahuan dan masyarakat.

Di samping itu ketika metode Mawdlû'îy disandingkan dengan metode-metode lain, maka akan muncul perbedaan-perbedaan antara lain:

\section{Perbedaan Metode Mawdlû'îy dengan Metode Analisis}

\begin{tabular}{|c|c|}
\hline Metode Mawdlû'îy & Metode Analisis \\
\hline $\begin{array}{l}\text { Mufasir dalam penafsirannya tidak } \\
\text { terikat dengan susunan ayat dalam } \\
\text { mushhaf, tetapi lebih terikat dengan } \\
\text { urutan masa turunnya ayat atau kro- } \\
\text { nologis kejadiannya. } \\
\text { Mufasir tidak membahas segala segi } \\
\text { permasalahan yang dikandung oleh } \\
\text { satu ayat, tapi hanya yang berkaitan } \\
\text { dengan pokok bahasan atau judul } \\
\text { yang ditetapkannya. } \\
\text { Mufasir dalam pembahasannya tidak } \\
\text { mencantumkan arti kosakata, asbâb } \\
\text { al-Nuzûl, munâsabah ayat dari segi } \\
\text { sistematika perurutan, kecuali dalam } \\
\text { batas-batas yang dibutuhkan oleh } \\
\text { pokok bahasannya. } \\
\text { Mufasir berusaha untuk menuntas- } \\
\text { kan permasalahan-permasalahan } \\
\text { yang menjadi pokok bahasannya. }\end{array}$ & $\begin{array}{l}\text { Mufasir biasanya hanya mengemuka- } \\
\text { kan penafsiran ayat-ayat secara berdiri } \\
\text { sendiri, sehingga persoalan yang diba- } \\
\text { has menjadi tidak tuntas, karena ayat } \\
\text { yang ditafsirkan seringkali ditemukan } \\
\text { kaitannya dalam ayat lain pada bagian } \\
\text { lain surat tersebut, atau dalam surat } \\
\text { yang lain. }\end{array}$ \\
\hline
\end{tabular}

\section{Perbedaan Metode Mawdlû́îy dengan Metode Komparasi}

Contoh perbedan antara metode Mawdlûîi dengan metode komparasi, adalah yang khusus membandingkan antara ayat dengan ayat seperti ayat:

\begin{tabular}{|c|c|}
\hline Surat al-An'âm ayat 151: & ولاتقتلو آلو لاد كممنإملاق طنحن نرزقكمو اياهم \\
\hline Surat al-Isrâ' ayat 31 : & ولاتقتلو آولاد كم خشية إملاق طنحن نرزقهمو اياهم \\
\hline \multicolumn{2}{|c|}{ Atau perbedaan antara : } \\
\hline Surat al-A'râf ayat 12 & قالمامنعك الاتسجداذامرتك طقال اناخيرمنه \\
\hline Surat Shâd ayat 75 & مامنعك انتسجدلماخلقت بيدي \\
\hline
\end{tabular}




\begin{tabular}{|c|c|}
\hline Metode Mawdlû́î & Metode Komparasi \\
\hline $\begin{array}{l}\text { Mufasir disamping menghimpun se- } \\
\text { mua ayat yang berkaitan dengan ma- } \\
\text { salah yang dibahas, ia juga mencari } \\
\text { persamaan-persamaan, serta segala } \\
\text { petunjuk yang dikandungnya selama } \\
\text { berkaitan dengan pokok bahasan } \\
\text { yang ditetapkan. }\end{array}$ & $\begin{array}{l}\text { Mufasir biasanya hanya menjelaskan } \\
\text { hal-hal yang berkaitan dengan perbe- } \\
\text { daan kandungan yang dimaksud oleh } \\
\text { masing-masing ayat tersebut atau per- } \\
\text { bedaan kasus atau masalah. } \\
\text { Seperti misal: al-Khathîb al-Iskâfî da- } \\
\text { lam kitabnya Durrâh al-Tanzîl wa } \\
\text { Gurrah al-Ta'wîl, (tidak mengarahkan } \\
\text { pandangannya kepada petunjuk- } \\
\text { petunjuk yang dikandung oleh ayat- } \\
\text { ayat yang dibandingkan). }\end{array}$ \\
\hline
\end{tabular}

Demikian pula ketika penulis mencoba melakukan pembahasan petikan ayat tentang HAM yang diawali dengan mengemukakan eksistensi hak-hak asasi manusia dalam al-Quran. Hal ini penting karena diduga kuat al-Quran telah banyak mengungkap ayatayat yang terkait dengan hak asasi manusia baik secara langsung maupun tidak langsung. Rincian unsur-unsur yang diteliti adalah uraian tentang keberadaan manusia di muka bumi. Obyek pokok yang diteliti adalah QS. al-Nisâ': 135, QS. al-Baqarah: 36 dan QS. alA'râf: 24 serta ayat-ayat lain yang relevan.

\section{Hakikat HAM dalam Redaksi al-Quran Surat al-Nisâ' Ayat 135}

Untuk melakukan kajian teradap normanorma hukum HAM dalam QS. al-Nisâ':135 adalah memahami terlebih dahulu redaksi lengkap ayat tersebut. Norma-norma hukum HAM dalam al-Quran hanya dapat diuraikan salah satunya dengan melihat, membaca, menerjemahkan, dan menganalisis redaksi ayat secara lengkap dalam QS. al-Nisâ': 135. Terlebih lagi ayat ini menjelaskan tentang kedudukan manusia sebagai mustakhlaf yang memiliki hak siyâsî dan sebagai musta'mir yang memiliki relevansi dengan normanorma hukum HAM dalam al-Quran.

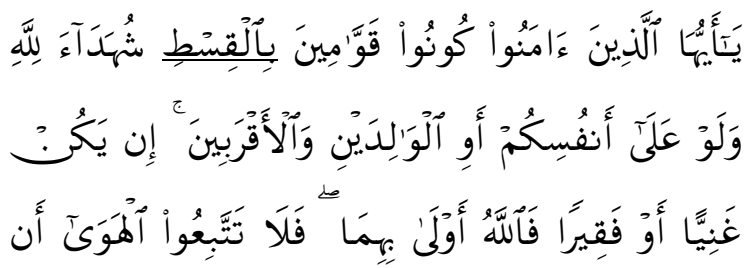

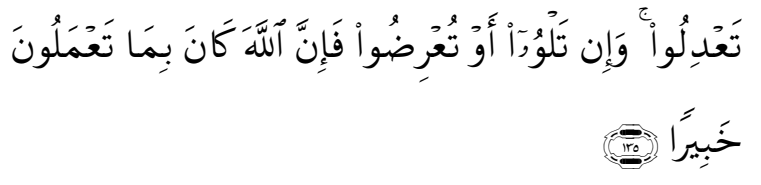

Wahai orang-orang yang beriman, jadilah kamu orang yang benar-benar penegak keadilan, menjadi saksi karena Allah biarpun terhadap dirimu sendiri atau ibu bapa dan kaum kerabatmu. Jika ia kaya ataupun miskin, maka Allah lebih tahu kemas-lahatannya. Maka janganlah kamu mengikuti hawa nafsu karena ingin menyimpang dari kebenaran. dan jika kamu memutar balikkan (kata-kata) atau enggan menjadi saksi, maka sesungguhnya Allah adalah Maha mengetahui segala apa yang kamu kerjakan.

Berdasarkan kebanyakan pendapat, sebab turunnya QS. al-Nisâ':135 dikemukakan oleh Ibnu Abi Hatim yang meriwayatkan bahwa al-Suddî mengatakan ayat ini turun pada Nabi Muhammad SAW. ketika seorang kaya dan seorang fakir berselisih dan mengadukannya kepada beliau. Kemudian Rasulullah SAW pun memihak kepada orang yang fakir karena menurut beliau orang fakir itu tidak menzalimi orang yang kaya. Sedangkan Allah tetap ingin agar beliau berlaku kepada orang yang kaya dan fakir tersebut. ${ }^{3}$

Pendapat serupa juga relatif sama menjelaskan bahwa QS. al-Nisâ': 135 dilatar-

3 Imâm Bayhaqî, Sunan al-Kubrâ (Beirut: Dâr al-Fikr. t.th), juz ke-7, hlm. 296. dan Imâm al-Hâkim, al-Mustadrak (Beirut: Dâr al-Fikr. t.th.), juz II, hlm. 238. Lihat pula dalam Editor, "Asbâb al-Nuzûl: Sejarah Turunnya Q.S. al-Nisâ: 135” dalam http://www.alislamu.com/4728/ surah-an-nisaa-ayat-102-sd-135/ diakses tanggal 4 Juli 2015. 
belakangi oleh riwayatkan oleh Ibnu Abî Hâtim yang bersumber dari al-Suddî: bahwa turunnya ayat ini QS. al-Nisâ': 135 yang berkenaan dengan pengaduan dua orang yang bersengketa, seorang kaya dan seorang lagi miskin. Rasulullah SAW membela pihak yang fakir dengan menganggap orang fakir tidak akan mengzhalimi orang kaya. Akan tetapi Allah tidak membenarkan tindakan Rasulullah SAW dan memerintahkan untuk menegakkan keadilan di antara kedua belah pihak. $^{4}$

Dalam ayat ini disebut lafazh "al-qisth" secara bahasa berarti bagian yang wajar dan patut. Lafazh "al-qisth" hampir setara maknanya dengan lafazh "al-'adl". Dari segi istilah, lafazh "al-qisth" mengandung pengertian memberikan sesuatu sesuai dengan bagiannya (wajar dan patut). Lafazh ini dekat maknanya dengan lafazh "al-khayr atau alihsân". Dalam konteks ini "al-qisth" tidak secara otomatis diartikan dengan "persamaan", tetapi yang lebih tepat adalah "memberikan hak seseorang secara proporsional".

Bagi para penegak hukum, terlebih ia seorang muslim yang beriman, jelas memiliki kewajiban untuk menegakan keadilan. Dengan kata lain, setiap muslim diharuskan menjadi penegak keadilan. Sesuai dengan kedudukan manusia sebagai penegak hukum, manusia dapat menjadi hakim (qadlî), pengacara (al-mahammî) dan sebagainya. Bahkan pada tingkat yang paling sederhana, kewajiban menegakan hukum wajib dilaksanakan di manapun sesuai dengan tuntutan syariat serta situasi dan kondisinya.

Al-Quran telah banyak mengungkap ayat-ayat yang terkait dengan hak asasi manusia baik secara langsung maupun tidak langsung. Ada sekitar 287 ungkapan hak dalam al-Quran dengan berbagai bentuknya. Pemakaian term "hak" dalam al-Quran tersebar di berbagai tempat dengan makna yang cukup beragam. Hanya saja, diakui bahwa tidak ditemukan term yang menunjuk pada hak asasi manusia secara langsung, kecuali dengan penggunaan partikel lâm (J)

4 Yusep Ridwan, Asbab Nuzul: Sejarah Turunnya Q.S. al-Nisâ: 135", dalam http://a lquran-asbabunnuzul.blogspot.com/2014/02/an-nisa-ayat-135.html, diakses tanggal 4 Juli 2015. yang berfungsi sebagai lâm al-tamlîk, berarti "bagi" atau "untuk".

Contoh dari penggunaan partikel "lâm" yang bermakna hak asasi manusia, seperti pada QS. al-Baqarah ayat 36 dan QS. al-A'râf: 24. Berdasarkan elaborasi ayat ditemukan bahwa kedua ayat di atas mengandung 2 macam hak asasi manusia yang sangat mendasar, yakni haqq al-istiqrâr dan haqq al-istimtâ'. Kedua hak tersebut merupakan hak asasi manusia dari dua segi. Pertama, ungkapan alQuran tentang HAM, telah terkandung kepada dua hak di atas. Artinya akumulasi hakhak yang ada dalam al-Quran dapat dikembalikan kepada dua hak tersebut. Misalnya, hak hidup; hak persamaan dan kebebasan; hak memperoleh perlindungan; hak kebebasan memilih agama, dan lain-lain. Kedua, kedua hak itu adalah ketetapan Tuhan sebagai perintah bagi manusia meninggalkan surga dan hidup di bumi. Dengan demikian, hakhak tersebut merupakan salah satu faktor bagi kehidupan manusia di bumi, terutama bila dikaitkan dengan QS. al-A'râf: 25 yang menegaskan bahwa manusia diberi hidup, dimatikan, dan dibangkitkan di bumi.

Hakikat HAM dalam al-Quran memiliki karakteristik yang khas, yakni bersifat teocentris, di mana posisi Tuhan mutlak segalanya dan manusia hanya bertugas mengabdi kepada-Nya (QS. al-Dzâriyât: 56). Ini mengandung isyarat yang amat mendalam, bahwa manusia tidak boleh mengorientasikan hidupnya kepada apa dan siapa pun kecuali kepada Allah (QS. al-Ikhlâsh: 1-2). Implikasi dari orientasi tauhid ini adalah manusia dilahirkan dengan hak dan kewajiban yang sama. Hal ini berbeda dengan konsep Barat sangat mementingkan perlindungan terhadap HAM dan kemerdekaan dasar dari individu-individu dengan pendekatan antropocentris, di mana manusia merupakan ukuran terhadap segala sesuatu. ${ }^{5}$

Hal-hal lainnya yang diungkapkan dalam al-Quran terkait dengan hakikat HAM yaitu adanya keseimbangan antara hak dan kewajiban manusia (QS. al-Baqarah: 228). Dengan demikian perbedaan pokok antara pemikiran

5 Abdul Hayyie (Penerjemah), Sebab Turunnya Ayat al-Quran (Jakarta: Gema Insani. 1994), hlm. 197206. 
Barat dan al-Quran tentang hak dan kewajiban sangat jelas. Pemikiran Barat lebih menonjolkan hak dari pada kewajiban, sebagai dampak dari paham individualisme dan materialisme yang berlebihan. Sedangkan alQuran cenderung menyeimbangkan antara hak dan kewajiban. Artinya, HAM merupakan imbangan dari kewajiban-kewajiban yang telah ditunaikannya.

Dalam hak hidup, al-Quran bukan hanya melarang membunuh orang lain (QS. al-Isrâ': 33), tetapi juga mewajibkan seseorang untuk melindungi hak hidup orang lain dari setiap

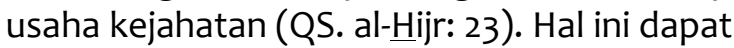
dilihat dari sanksi yang dijatuhkan al-Quran terhadap seorang pembunuh dengan memerdekakan budak. (QS. al-Nisâ" [4]: 92). Dalam konteks ini penulis berpendapat bahwa masalah kehidupan bukan hanya dapat dikaitkan dengan hak, tetapi juga dapat disebut sebagai kewajiban. Implikasi lebih jauh dari uraian ini akan melahirkan hak baru berupa hak kemerdekaan dan kebebasan. ${ }^{6}$

Demikian pula ketika menjelaskan hak untuk bebas dalam al-Quran bukan hanya memberi hak kepada manusia untuk bebas mengeluarkan pendapat (QS. al-A'râf: 185), tetapi juga mewajibkan manusia menyampaikan kebenaran (QS. Ali 'Imrân: 104 dan juga dalam QS. Ali 'Imrân: 110). Uraian-uraian ini sekaligus membedakan dengan hak-hak asasi manusia dalam pandangan Barat yang lebih cenderung "mempertuhankan" kebebasan yang tiada batasnya.

Tidak terkecuali dalam hal hak untuk memiliki suatu benda dalam al-Quran diwajibkan agar manusia lebih giat mencari harta agar terhindar dari kemiskinan (QS. alBaqarah: 168). Meskipun demikian, motivasi al-Quran dalam memperoleh harta tetap dibatasi guna mencegah pemerasan seseorang atas diri orang lain. Dalam hal ini, alQuran memberi tuntunan kepada manusia dalam memperoleh harta benda (QS. alNisâ": 29).

\section{Norma-norma Hukum HAM dalam Munâsabah Ayat Al-Quran}

Berbicara tentang dasar-dasar hak-hak asasi manusia dalam al-Quran, tentu tidak

6 Ibid. terlepas dari kedudukan manusia di muka bumi. Sebagai makhluk yang diciptakan dalam bentuk fisik yang sebaik-baiknya (QS. alTîn: 4), manusia dikaruniai kelengkapan pendukung berupa pendengaran, penglihatan, akal (QS. al-Mulk: 23; QS. al-Sajdah: 9; QS. alNahl: 78), dan sebagainya. Karunia inilah yang membedakan manusia dengan makhluk lainnya. Kesemuanya itu, merupakan sarana bagi manusia dalam melakukan segala aktivitas dan tindakan yang disukainya.

Dengan potensi dasar itu Allah menjadikan manusia sebagai mustakhlaf dan musta'mir di muka bumi karena didasarkan pada kemampuan manusia untuk mengembangkan potensi berpikir baik yang terkait dengan makhluk hidup (QS. al-Nahl: 79; QS. al-Gâsyiyah: 17) maupun yang terkait dengan penciptaan alam (QS. al-Rûm: 22-23-24-25) sebagai tanda-tanda kekuasaan Allah. Konsekuensi penunjukan manusia sebagai khalifah menunjukkan bahwa manusia memiliki wilayah kekuasaan.

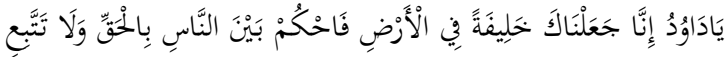

$$
\begin{aligned}
& \text { الهوَى ... }
\end{aligned}
$$
kan:

Dalam QS. Shâd: 26, misalnya disebut-

Salah satu aspek penting yang terungkap pada ayat di atas adalah pengangkatan Nabi Daud sebagai khalifah dengan tugas pokok menegakkan hukum dengan benar di tengah-tengah masyarakat. Ayat tersebut menunjukkan betapa Tuhan menekankan pentingnya keadilan, sehingga permintaan untuk menegakkan hukum secara hak diikuti dengan peringatan agar tidak menyimpang dari kebenaran dengan mengikuti hawa nafsu.

Di samping kedudukan manusia sebagai mustakhlaf di muka bumi, al-Quran juga mengungkap kedudukan manusia sebagai musta'mir yakni pembangun kemakmuran. Dasar statemen ini adalah firman Allah QS. Hûd: 61 sebagai berikut:

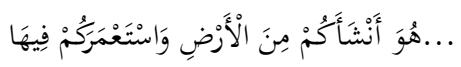

...Dia telah menciptakan kamu dari bumi (tanah) dan menjadikan kamu pemakmurnya...

Kata kerja ista'mara merupakan ungkapan yang menunjukkan pada kedudukan 
manusia. Kata kerja ini dibentuk dari kata kerja yang lain, yaitu عمر . Kata ini terdiri dari huruf-huruf 'ain, mîm dan râ'. Makna pokok huruf-huruf ini, "kekekalan dan zaman yang panjang, dan sesuatu yang meninggi" (seperti suara atau lainnya). Analisis morfologi kata ini adalah 'amara - ya'muru yang bermakna leksikal "panjang usia, banyak harta, menghuni, memanjangkan usia, membangun dan mengurus sesuatu dengan baik".

Mengacu kepada penjelasan di atas, maka dapat dipahami bahwa عمر adalah memakmurkan sesuatu sebagai upaya membangun untuk mendapatkan kehidupan yang lebih maju dan lebih berkualitas. Lafal عمر dengan segala bentuknya ditemukan 28 kali dalam al-Quran. al-Quran dalam beberapa ayatnya menggunakan ya'muru sebanyak dua kali, masing-masing terdapat pada QS. al-Tawbah: 17-18. Dalam ayat ini, kata ya'muru digandengkan dengan kata masjid. Hal ini berarti memakmurkan mesjid dengan jalan membangun, memelihara, membersihkan dan i'tikâf. Sedangkan QS. al-Rûm: 9 menggunakan kata lampau 'amarû digandengkan dengan ardl.

Gambaran di atas mengandung arti anjuran untuk membangun bangunan, dan mengelolanya untuk memperoleh manfaatnya. Untuk memperoleh gambaran lebih jauh tentang wujud hak asasi manusia dalam alQuran, perlu ditelusuri ayat-ayat yang berkenaan dengan eksistensi manusia di bumi. Di antaranya QS. al-Baqarah: 36 yang berbunyi :

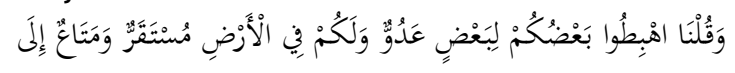

Para ulama tafsir memandang fi'il 'amr

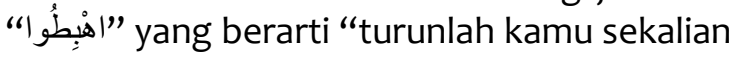
dari surga" ditujukan kepada Adam dan Hawa 'alayhima al-salâm dan setan 'alayhi alla'nat. Pandangan ini dikemukakan antara lain oleh Rasyîd Ridlâ. Sementara itu, ulama salaf cenderung berpendapat bahwa setan yang dimaksud dari klausa di atas adalah Iblis.

Kalimat perintah yang ditujukan kepada Adam, Hawa dan Iblis didasarkan pada penggunaan kalimat perintah yang ditujukan kepada orang kedua dalam bentuk jamak, tetapi bila diperhatikan beberapa ayat sebe- lumnya, ternyata kalimat perintah yang khusus ditujukan kepada Iblis untuk keluar dari surga telah mendahului kalimat perintah sebelumnya. Perintah itu terdapat pada QS. al-A‘râf ayat 13 "فاهبط" dan pada ayat 18 " - (أخرج"،

Menurut al-Mawdudî perintah pokok

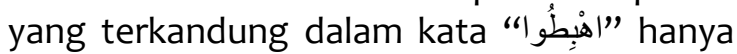
ditujukan kepada Adam dan Hawa karena Iblis telah diperintahkan turun sebelumnya setelah menolak untuk sujud kepada Adam. Pendapat lainnya juga dikemukakan oleh Abû Shâlih ${ }^{8}$ bahwa penggunaan kata jamak “اهُبْطُو ditujukan kepada Adam, Hawa dan kehidupan, yang ketiganya merupakan satu kelompok. Sedangkan al-Hasan berpendapat bahwa penunjukan kata jamak ditujukan kepada Adam, Hawa dan godaan.

Dari berbagai uraian di atas dapat dipahami bahwa perintah keluar dari surga terhadap Iblis pada ayat 24 hanya merupakan perulangan atau sekedar penegasan, sedang bagi Adam dan Hawa perintah itu merupakan konsekuensi logis yang harus mereka terima setelah keduanya melanggar. Dengan

7 Bambang Iriana Djajaatmadja (Penerjemah), Hak-hak Asasi Manusia dalam Islam (Jakarta: Bumi Aksara. 2000). Hlm. 89.

8 Abû Shâlih adalah salah satu pengikut Ibnu 'Abbâs yang turut meriwayatkan hadits yang sezaman dengan sahabat lainnya. Nama aslinya adalah Ishaq bin Najih diberi gelar Abû Shâlih. Abû Thâhir Muhammad ibn Ya'qub al-Fairuz Abadi, Tanwîr al-Muqâbas min Tafsîr Ibn 'Abbâs, 400 halaman, diterbitkan dan dimaknai versi pesantren oleh al-Ma'had al-Islami asSalafi Hidayatuth Thullab Pondok Pesantren Petuk, Kec. Semen, Kab. Kediri, tanpa tahun terbit; didapatkan dari Pondok Pesantren Petuk [Tafsir alQuran]. Kitab ini adalah kitab tafsir al-Quran yang dikenal dengan Tafsir Ibn 'Abbâs. Bukan karena kitab ini ditulis langsung oleh Ibn 'Abbâs, melainkan oleh ulama yang memiliki mata rantai transmisi keilmuan, khususnya tafsir al-Quran, yang sampai kepada Ibn 'Abbâs. Penulis menyebutkan bahwa transmisi penafsiran alQuran versi Ibn 'Abbâs pertama kali diperoleh dari 'Abdullah ibn al-Makmûr alMakmûr al-Harawî sendiri memperoleh dari bapaknya, dan bapaknya memperoleh dari Abû 'Abdillah, dari Abû Ubaidillah Mahmud ibn Muhammad al-Razî, dari 'Ammar ibn 'Abdul Majid al-Harawî, dari 'Alî ibn Ishaq al-Samarqandî, dari Muhammad ibn Marwan, dari alKalabî, dari Abû Shâlih dari Ibn 'Abbâs. Lihat dalam Editor, Risalah Kitab Tanwîr al-Muqâbas min Tafsîr Ibn "Abbâs" artikel dalam http://rumahkitab.com/all-project-list/tanwir-al-muqabas-min-tafsir-ibn-abbas/, diakses 2 Juli 2015 . 
demikian maksud pokok perintah itu tertuju hanya kepada Adam dan Hawa, suatu pasangan yang secara pisik memiliki potensi untuk berkembang biak di bumi.

Selanjutnya Allah menegaskan dalam klausa ayat berikut:

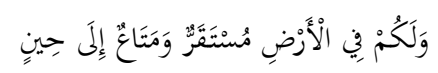

Terdapat dua kata kunci yang perlu dielaborasi dan diinterpretasi lebih mendalam untuk memahami kandungan ayat dengan sempurna dan komprehensif. Kedua kata itu adalah mustaqarr dan matâ'.

Lafal mustaqarr dengan segala bentuknya ditemukan sebanyak 35 kali dalam alQuran. Istilah mustaqarr merupakan ism makân (kata benda yang menunjukkan tempat) dengan analisis morfologis - بستقر - بستقر استقرا yang dibentuk dengan kata kerja dasar

berakar kata dengan huruf shahih yang asli yakni qâf dan râ', lafal قرن mempunyai arti البردو التمكن "dingin dan bertempat tinggal”. Kata qarra sama dengan istaqarra.

Al-Qarr dapat berarti صب المساء في الثنى (menuangkan air pada sesuatu tempat; dapat pula berarti صب الكلام في الأذن (mengungkapkan/memperdengarkan pembicaraan pada telinga). Menurut Muhammad Rasyîd Ridlâ, ${ }^{9}$ kata mustaqarr bisa bermakna masdar (verbal noun) yaitu al-istiqrâr (bertempat tinggal) dan bisa pula bermakna ism makân.

Dalam beberapa ayat al-Quran, kata mustaqarr dapat berarti tempat menetap, berdiam, tinggal (lihat misalnya, QS. al-A'râf: 24; QS. al-Baqarah: 36; QS. al-An'âm: 98; QS. al-Furqân: 24, 66, 76; QS. Hûd: 6), waktu terjadinya sesuatu (lihat misalnya, QS. al-An'âm: 67), tempat kembali (lihat misalnya, QS. alQiyâmah: 38). Dalam al-Quran terdapat juga kata mustaqirr (ism fấil dari istaqarra), berarti waktu yang telah ditetapkan (QS. alQamar: 38) dan tempat peredaran (QS. Yâsîn: 38).

Lafal matâ' dan yang seakar dengannya dapat dijumpai pada 35 tempat dalam al-

9 Muhammad Râsyid Ridlâ, tafsîr alManâr, Maktabah asy-Syamilah/pdf, juz 1 dan lihat pula M. Quraisy Shihab, Studi Kritis Tafsir al-Manar; Karya Muhammad 'Abduh dan M. Râsyid Ridlâ (Bandung: Pustaka Hidayah. 1994), hlm. 26.
Quran. Matâ' adalah kata benda yang dibentuk dari kata kerja mata'a yang terdiri dari tiga huruf yang semuanya shalihat, yaitu almîm, al-tâ', al-‘ain, yang menunjukkan pada makna pemanfaatan, tersedianya kesempatan yang baik. aatâ' sama dengan mut'at.

Al-Qâsimî memandang kata matâ' dengan makna tamattu' (kesenangan), dan ma'îsyatan (kehidupan). Sementara itu Muhammad Rasyîd Ridlâ mengartikan matâ dengan sesuatu yang dapat dimanfaatkan termasuk makanan dan minuman yang dihasilkan dari perut bumi dan segala bentuk kesenangan dunia. Bahkan al-Quran sendiri pada beberapa tempat mengungkapkan kata matâ' dengan arti kesenangan hidup, misalnya dalam QS. al-Baqarah: 36; QS. al-A'râf: 24; QS. al-Anbiyâ': 111; QS. Ali 'Imrân: 14, 185; QS. al-Hadîd: 28; pemberian untuk menyenangkan, pemberian yang patut, pemberian nafkah, misalnya dalam QS. al-Baqarah: 236, 240, 241; bahan yang berguna, misalnya dalam QS. al-Wâqi'ah: 73; barang-barang, QS. Yûsuf: 17, 65; alat-alat, QS. al-Ra'd: 17; harta benda, dalam QS. Yûsuf: 79; QS. al-Nisâ”: 102.

Klausa ولكم في الأرض مستقر و متاع الي حين menggambarkan eksistensi hak. Partikel yang menunjukkan makna "pemberian hak" تمليك adalah partikel "lâm" dalam ungkapan " "كَكْمَ bagi (untuk) kamu. Dengan demikian, meskipun ayat 24 QS. al-A'râf lebih dahulu turun daripada ayat 36 QS. al-Baqarah, namun keduanya tetap secara tegas memberikan hak-hak kepada Adam berupa hak bertempat tinggal dan hak menikmati fasilitas yang ada di bumi.

Menurut Muin Salim, ${ }^{10}$ kedua hak di atas merupakan hak asasi manusia dari dua segi. Pertama, ungkapan al-Quran tentang hakhak manusia, telah terkandung kepada dua hak diatas. Artinya akumulasi hak-hak yang ada dalam Al-Quran dapat dikembalikan kepada dua hak tersebut. Kedua, kedua hak itu adalah ketetapan Tuhan sebagai perintah bagi manusia meninggalkan surga dan hidup di bumi. Dengan demikian, hak-hak tersebut merupakan salah satu faktor bagi kehidupan manusia di bumi, terutama bila dikaitkan

10 Abd. Muin Salim, Beberapa Aspek Metodologi Tafsir al-Quran (Ujung Pandang: LSKI. 1990), hIm. 49. 
dengan QS. al-A'râf ayat 25 yang menegaskan bahwa manusia diberi hidup, dimatikan dan dibangkitkan di bumi.

Pada gilirannya, dapat dipahami bahwa keterangan al-Quran tentang hak-hak kemanusiaan disertai dengan pandangan hidup yang mengakui adanya kehidupan sesudah mati, sehingga kesempatan hidup yang sebatas itu hendaknya dimanfaatkan dengan sebaik-baiknya, hendaknya manusia menggunakan hak-haknya dengan penuh tanggung jawab, tidak melakukan penyimpangan-penyimpangan.

Ayat di atas menunjukkan bahwa manusia diciptakan di muka bumi, kemudian hidup selama umur yang telah ditentukan termasuk segala jenis makhluk. Selanjutnya, dari bumi itu pula manusia dan segala jenis makhluk dimatikan ketika umur telah habis, dan dari bumi itu pula manusia dikeluarkan setelah mati sebagai kebangkitan menuju hidup lain.

Menganalisis dan mencermati berbagai keterangan di atas dapat dipahami bahwa alQuran mengakui keberadaan hak-hak asasi manusia yang telah melekat sebagai manusia yang wajar. Hak-hak yang dimaksud adalah haq al-Istiqrâr, yakni hak untuk menetap dan berdiam di muka bumi dan haq al-Istimtâ', yakni hak untuk memanfaatkan fasilitas yang ada di bumi sebagai rezki Tuhan.

Kedua hak di atas dapat diklasifikasikan secara parsial dalam wujud yang lebih sederhana, misalnya hak hidup, hak memiliki, hak kemerdekaan beragama dan hak menyatakan suatu pendapat. Hak-hak di atas adalah pemberian Tuhan berupa kelapangan hidup di bumi dan perasaan senang dalam memanfaatkan isinya. Dengan demikian, setiap perlakuan yang merampas hak-hak itu berarti mengabaikan hak-hak yang diberikan Tuhan kepada manusia yang diidentifikasi sebagai hak-hak kemanusiaan.

Oleh karena ia pemberian Allah, maka tak satu pun negara, pemerintah termasuk masyarakat di dunia ini yang berwenang dalam membuat perubahan menyangkut hak-hak yang Allah telah berikan itu. Bahkan tidak seorang pun diberi hak untuk menghapuskan atau mencabutnya. Hak-hak asasi manusia berakar pada kodrat pribadi manusia sendiri.

Sementara itu dapat digambarkan bahwa sebagai makhluk sosial manusia harus mewujudkan hak asasi dalam setiap aspek kehidupan. Dalam lingkungan masyarakat, setiap orang pasti bergaul dengan sesama manusia, bertukar kepentingan dalam bermuamalah dengan melakukan jual beli, sewa menyewa. Kegiatan pergaulan demikian menjadi ciri kehidupan berbudaya.

Dalam rangkaian kehidupan yang demikian, al-Quran tidak saja menghendaki ditegakkannya keadilan yang menjamin persamaan hak, tetapi lebih dari pada itu dikehendaki pula terlaksananya sikap kebajikan (ihsân). Dengan demikian posisi manusia sebagai karâmah insâniyyah yang memberi martabat tinggi, yaitu martabat kemanusiaan, tetap terjamin.

\section{E. Norma-norma Hukum HAM dalam al- Quran}

\section{Manusia sebagai Mustakhlaf}

Manusia adalah makhluk yang memiliki keistimewaan berupa bentuk fisik yang bagus dan kemampuan menggunakan akal pikirannya. Karena itu, manusia diberi kedudukan oleh Allah sebagai seorang khalifah di muka bumi. Konsekuensi penunjukan manusia sebagai khalifah menunjukkan bahwa manusia memiliki wilayah kekuasaan. (QS. Shâd: 26).

Dalam banyak diskusi dan debat di kalangan sarjana muslim nyaris tidak mendapatkan keterangan lebih jauh tentang konsep yang terkandung dalam "khalifah". Akan tetapi dalam QS. al-Baqarah: 30 telah diungkapkan bahwa manusia pertama Adam juga seorang khalifah. Karena itu terdapat persamaan-persamaan dengan ayat tentang pengangkatan Dawud sebagai khalifah, baik dalam persamaan dalam redaksi maupun dalam makna dan konteks uraian.

Hal yang menarik untuk diperbincangkan bahwa pengangkatan Adam sebagai khalifah dilukiskan dalam bentuk tunggal yakni innî (sesungguhnya Aku) digandengkan dengan kata jấil berarti akan mengangkat. Sedangkan pengangkatan Dawud sebagai khalifah digambarkan dalam bentuk plural innâ diikuti dengan fi'il mâdlî (kata kerja ben- 
tuk lampau) ja'alnâka.

Quraish Shihab ${ }^{11}$ memandang penggunaan nun jamak dalam kata innâ (sesungguhnya Kami) dalam frase إِنَّا جَعَلْنَاكَ mengandung makna keterlibatan pihak lain bersama Allah dalam pengangkatan Dawud sebagai khalifah. Sedang dalam kasus yang sama terhadap pengangkatan Adam sebagai khalifah, Allah melukiskan dengan kata innî yang mengandung makna bahwa kekhalifahan yang dimaksudkan baru berupa rencana (Aku akan mengangkat).

Di samping makna ini, dapat pula dikemukakan makna lain bahwa ketika peristiwa pengangkatan terjadi, tidak ada pihak lain yang terlibat bersama Allah. Ini berarti Nabi Dawud a.s dalam pengangkatannya sebagai khalifah dituntut untuk memperhatikan kehendak masyarakat karena mereka itu termasuk pula mustakhlaf.

Makna khalifah di kalangan ulama tafsir masih menimbulkan berbagai perbedaan pendapat. Ibn Katsîr ${ }^{12}$ menafsirkan kata khalifah sebagai kepala pemerintahan umat Islam. Pandangan serupa juga dikemukakan oleh al-Qurthubî. Menurut al-Wâhidî dan alSyawkânî, keduanya cenderung memahami kata khalifah sebagai kepemimpinan para Nabi secara bergantian guna menegakkan hukum Allah. Dalam konteks ini, kata khalifah dapat juga mengandung dimensi eskatologis. Ini berarti bahwa tugas dan tanggung jawab duniawi tidak terlepas dari dimensi ukhrawi.

Pandangan lebih luas dikemukakan oleh Fairûzabâdî dari Ibn Abbâs dan al-Zamakhsyarî bahwa kedudukan khalifah mencakup kedudukan raja-raja dan Nabi-nabi sebagai pemerintah. Menganalisis dan mencermati berbagai uraian di atas, kelihatannya mereka memiliki pendekatan yang sama dengan melihat konsep khalifah dalam perspektif kepemimpinan dan pemerintahan.

Benang merah yang dapat diambil dari konsep manusia dalam al-Quran sebagai mustakhlaf antara lain: Pertama, merujuk kepada QS. al-Isrâ': 70 yang menjelaskan bah-

11 M. Quraish Shihab, Tafsir al-Misbah: Pesan dan Keserasian al-Quran: Lentera Hati (Jakarta: Gema Insani Press. 2005), hlm. 140.

12 Ibid. wa manusia adalah makhluk yang dimuliakan oleh Allah SWT dibandingkan makhlukmakhluk lainnya. Ini menandakan manusia memperoleh hak yang diberikan oleh Allah; Kedua, merujuk kepada QS. al- $\underline{\text { Hijr }}$ ayat 28 yang menjelaskan bahwa manusia memiliki sifat basyariah sesuai dengan fitrahnya sebagai makhluk Allah yang paling sempurna, memiliki ruh, akal, nafs, dan qalb; Ketiga, merujuk kepada QS. al-Baqarah ayat 30 yang menjelaskan bahwa karena kedudukannya yang dimuliakan Allah SWT, memperoleh hak-hak dari-Nya, dan memiliki sifat basyariyah dan keunggulan daripada makhlukmakhluk lainnya, Allah menjadikan manusia sebagai satu-satunya makhluk yang diberi amanat menjadi "khalifah" di muka bumi. Kasus pengangkatan Adam dan Dawud sebagai khalifah dalam konteks yang berbeda menunjukkan ke-mustakhlaf-an manusia.

Ringkasnya, jabatan khalifah mengandung konsep politik. Dengan demikian, QS. Shâd: 26 lebih fokus pada kedudukan dan peran Nabi Dawud sebagai pemimpin politik, di samping memberi keterangan tentang fungsi kekhalifahan manusia, yakni menegakkan hukum dalam kehidupan masyarakat dengan cara yang benar. Ini berimplikasi terhadap munculnya hak-hak siyâsî masyarakat.

\section{Manusia Sebagai Musta'mir}

Sebagaimana dikemukakan sebelumnya bahwa manusia, di samping sebagai khalifah, juga diberi kedudukan oleh Allah sebagai musta'mir sebagaimana dinyatakan Allah dalam QS. Hûd: 61. Kata ista'mara yang tercantum pada ayat di atas, terdiri dari huruf sîn dan tâ' sewazan dengan istaf'ala yang berarti "meminta" seperti dalam kata istagfara yang berarti "meminta ampunan". Arti lain kedua huruf ini adalah "menjadikan" seperti pada kata hajar yang berarti "batu", bila digabungkan dengan huruf sîn dan tâ' sehingga terbaca istahjara, maka maknanya adalah "menjadi batu".

Berdasarkan uraian di atas, kata ista'marakum dapat berarti "menjadikan kamu" atau "meminta/menugaskan kepada kamu" mengelola bumi guna memperoleh manfaatnya. Dengan demikian, ayat هوانشأكم menjelaskan bahwa yang من الأرض واستعمركم فيها 
wajib disembah adalah Tuhan yang telah menjadikan manusia dan memberinya kekuasaan untuk menghuni dan mengelola bumi.

Sementara itu Ibn Katsîr memahami adanya kekuasaan yang Allah berikan kepada manusia untuk mengolah bumi dengan isinya. Dengan demikian manusia dapat menggunakan kekayaan alam dan membangun peradaban serta mewujudkan kesejahteraan dan kemakmuran hidupnya di alam ini. Namun demikian kekuasaan manusia ini tetap dibatasi dengan berbagai larangan, misalnya larangan melakukan pengrusakan alam lingkungan, baik biotik maupun abiotik atau flora dan fauna. Dalam kaitan ini ada dua term yang digunakan al-Quran untuk menunjukkan larangan merusak dan perintah memelihara alam lingkungan. Kedua term itu adalah ifsâd dan ishlâh.

Untuk mengetahui lebih jauh dapat dilihat dalam QS. al-A'râf: 56 sebagai berikut:

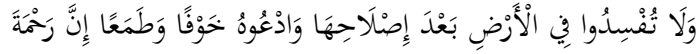

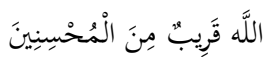

Kandungan pokok ayat di atas adalah larangan merusak sekaligus perintah memelihara bumi. Di sini dapat dinyatakan term ishlâh mengandung makna alam semesta diciptakan Allah dalam keadaan baik (shâlih $\underline{\text { ), }}$ harmonis dan sejahtera. Tetapi setelah manusia menghuni bumi, timbullah kerusakankerusakan sebagai akibat ulah manusia. Allah pun mengutus utusan-Nya untuk menyeru manusia agar mereka sadar dan berbuat baik. Karena itu usaha utusan Allah itu pada hakekatnya adalah usaha-usaha pembangunan, perbaikan atau pembaruan dan disebut ishlâh.

Mencermati beberapa ungkapan di atas, dapat dipahami bahwa konsep isti'mâr dan ishlâh bertujuan agar manusia dapat menjalani kehidupan di muka bumi dengan kehidupan sejahtera dan berkualitas. Cita-cita kehidupan ini dapat tercapai dengan cara mengolah, mengelola dan memelihara segala fasilitas yang telah ada di bumi ini.

Pernyataans di atas tentu masih perlu penelusuran lebih jauh, untuk mengetahui apakah makna demikian yang dimaksud. Ternyata, dalam al-Quran terungkap sejarah Nabi Shalih beserta kaumnya bangsa Tsamud yang oleh Allah diberi kekuasaan serta menjadikannya sebagai makhluk pembangun atau beradab.

Sejarah Nabi Shalih dan kaumnya sebagaimana diungkapkan dalam al-Quran, memperlihatkan peradaban mereka yang lebih maju dibanding dengan dua kaum yang mendahuluinya, yaitu kaum Nabi Nûh dan kaum Nabi Hûd. Kaum Nûh adalah masyarakat agraris yang menyembah berhala. Kedatangan Nabi Nûh kepada mereka tidak membuat mereka beriman, bahkan mereka lebih congkak lagi dan mempertahankan kepercayaan mereka yang salah, yakni mempertuhankan berhala. Akhirnya mereka dipunahkan dengan air bah kecuali sebagian kecil dari mereka yang beriman dan diselamatkan di atas bahtera Nabi Nûh a.s.

Menganalisis dan mencermati ungkapan di atas, dapat dipahami bahwa bangsa-bangsa terdahulu disamping menghuni suatu wilayah tertentu, juga telah membangun peradaban dan memanfaatkan potensi alam sekitar mereka untuk kemakmuran hidup bersama. Dengan demikian, kata 'isti'mâr' mengandung hak atau kewenangan manusia untuk memakmurkan bumi sebagai upaya mencapai kehidupan yang lebih baik dan maju.

Karena itu, bila ditilik lebih jauh maka konsep isti'mâr akan melahirkan hak-hak asasi manusia sebagaimana konsep khalifah yang memunculkan hak-hak siyâsî. Pendek kata, penulis dapat memahami bahwa QS. Hûd ayat 61 menegaskan tentang peran dan fungsi manusia sebagai pengembang, pembangun dan pencipta. Hal ini juga menegaskan bahwa manusia diciptakan dari bumi dan dijadikan penghuni yang menggarapnya untuk memakmurkannya. Segala fasilitas dan bahan-bahan kebutuhan yang terdapat di muka bumi yang terhampar luas, disediakan bagi manusia. Tentu bahan yang dimaksud bukan bahan-bahan jadi, akan tetapi semuanya memerlukan proses dan pengolahan. Dalam kondisi ini, daya cipta manusia amat diperlukan.

Islam adalah agama yang universal dan komprehensif yang melingkupi aspek keyakinan (aqidah), hukum (syariat), dan etika/moral (akhlak). Ketiga aspek itu terinternalisasi dalam dua pola hubungan yang sa- 
ngat unik antara manusia dengan Allah dan hubungan manusia dengan manusia. Dari ketiga aspek itu pula terbentuk dua konsep yakni konsep hak dan kewajiban (the concept of the rights and obligations) dan konsep tujuan hukum syara' (maqâshid al-syarî́ah), yang selanjutnya dikembangkan para ahli hukum sebagai kerangka teoritis perumusan konsep Hak Asasi Manusia (HAM) dalam hukum Islam.

Pada prinsipnya, kerangka filosofis konsep HAM dalam hukum Islam berakar pada tiga hal berikut. Pertama, konsep tentang manusia (the concept of human being); Kedua, konsep tentang hak dan kewajiban (the concept of the rights and obligations); dan Ketiga, konsep tentang penegakan hukum hak asasi manusia (the concept of human rights law). Ketiga konsep tersebut disinyalir menjadi persoalan paling fundamental yang membedakan konsep HAM dalam hukum Islam dan hukum Barat. ${ }^{13}$

Untuk melacak geneologi pola hubungan antara hukum Islam dan HAM, dapat digunakan beberapa pendekatan, antara lain: filosofis, historis, sosiologis dan yuridis. Secara filosofis, telah penulis jelaskan sebelumnya norma-norma hukum tentang asalusul manusia (the creation of human being), hak dan kewajiban (the concept of the rights and obligations), dan hukum HAM (the concept of human rights law). Problem ontologis tampak pada perbedaan teori tentang hakikat manusia dalam hukum Islam dan hukum Barat.

Dalam hukum Islam, secara fitrah setiap orang terlahir dalam keadaan bebas dan sama dalam harkat dan martabat (all human beings are born free and equal in dignity and rights), yang berpijak kepada pemberian otorisasi hak dan kewajiban oleh Allah kepada manusia. Sedangkan dalam hukum Barat, hak asasi merupakan sesuatu yang ada dengan sendirinya secara alami. Namun keduanya sama-sama menjadi dasar bagi

13 Deni K. Yusup, “Prinsip-prinsip Universal Hak Asasi Manusia dalam Hukum Islam" makalah dalam Konferensi Internaional Islam dan Hak Asasi Manusia pada Pusat Studi Islam, Universitas Islam Indonesia (UII), Yogyakarta, November 2012. adanya premis bahwa setiap individu memiki hak asasi dalam harkat dan martabat (everyone has a rights and dignity) dan pengakuan hak setiap manusia untuk mendapatkan keadilan (the justice right), serta kewajiban terhadap orang lain (where are the rights, there are the obligations). Ketiga prinsip tersebut semakna dengan asas resiprositas dalam konsep HAM.

Kemudian secara historis, meskipun para filosof dan sejumlah imperium Barat telah memperkenalkan beberapa statuta tentang dasar-dasar hukum HAM sampai ditetapkannya Universal Declaration of Human Rights (UDHR) pada 10 Desember 1948. Akan tetapi, ide pembentukan hukum HAM di dunia Barat justru baru muncul setelah berakhirnya Perang Dunia II (World War) dan memasuki fase Perang Dingin (Cold War). Padahal jauh sebelum itu, Rasulullah SAW pun telah memperkenalkan suatu platform Piagam Madinah (Medina Constituion) yang syarat dengan pengakuan terhadap norma-norma hukum HAM universal.

Selain itu, tanpa memperdebatkan geneologi lahirnya HAM di dunia Barat dan Islam, yang penting untuk ditegaskan di sini adalah konsep HAM Barat dalam bentuk Universal Declaration of Human Rights (UDHR) tanggal 10 Desember 1948 dengan konsep HAM Islam dalam bentuk Piagam Madinah dan Universal Islamic Declaration of Human Rights (UIDHR) hasil konferensi OKI tanggal 19 September 1981, jelas memiliki kesamaan tujuan yakni untuk meyakinkan perlindungan yang efektif atas hak-hak bagi semua manusia di manapun mereka berada, termasuk di negara yang tidak menjamin keberadaan hak itu dalam undang-undang dasar mereka, serta menghindarkan diri dari ketidakjelasan proses-proses politik, hukum dan administratif. Sehingga HAM menjadi sangat fundamental, harus dilindungi melalui konsensus dan kerjasama internasional, serta diakui keberadaannya dalam undang-undang dasar dan sistem hukum nasional.

\section{F. Penutup}

Adanya pandangan yang menyebut relasi hukum Islam dan HAM juga dapat dilacak melalui pendekatan sosiologis dan antro- 
pologis disebabkan keduanya terkait dengan aspek-aspek tradisi, budaya dan keyakinan dalam kehidupan manusia. Bahkan Universal Declaration of Human Rights (UDHR) sengaja telah berusaha tidak menggunakan agama apapun untuk menjustifikasi ide-ide dasarnya agar ia bisa menemukan dasar yang sama bagi mereka yang beragama maupun tidak.

Namun demikian tapi tidak berarti bahwa UDHR hanya bisa didasarkan pada justifikasi sekuler, karena cara seperti itu tidak bisa menjawab persoalan bagaimana melegitimasi dan mengesahkan HAM berdasarkan perspektif yang sangat beragam di dunia ini. Dengan demikian, deklarasi itu justru memberikan kesempatan kepada para penganut agama atau kepercayaan, semua tradisi dan budaya untuk membangun komitmen mereka kepada deklarasi itu, dengan menggunakan norma-norma yang terdapat dalam kepercayaan atau agama, tradisi dan budaya yang mereka miliki.

Ada sebuah tantangan yang perlu dijawab yakni pemahaman yang dianut kalangan orientalis Barat yang menyatakan bahwa hukum Islam cenderung mengabaikan prinsip-prinsip HAM yang universal. Mereka beranggapan bahwa konstruksi hukum Islam yang dibangun oleh para imam mazhab dari sumbernya (al-Quran dan Sunnah Nabi) pada masa awal penyusunan kitab-kitab fikih, misalnya dalam bidang hukum perdata dan pidana Islam, tidak mewakili kepentingan mereka untuk menggaransi prinsip-prinsip HAM.

Namun sebagai sumber utama hukum Islam, umat muslim meyakini sepenuhnya bahwa meskipun seringkali terjadi pemahaman yang paradok dalam melihat kompatibiltas antara hukum Islam dan HAM baik secara konsep maupun aplikasinya, namun pembatasan relasi keduanya lebih bersifat individual dan bukan universal karena alasan mayoritas dan minoritas, serta keyakinan agama yang bersifat absolut. Hal ini sekaligus menjadi pembuktian bahwa kesulitan memahami HAM dalam Islam bukan terletak pada menerima atau menolak HAM dalam alQuran, tapi kebanyakan pemikir cenderung kesulitan memahami HAM dalam al-Quran lebih dari menolak al-Quran itu sendiri sebagai Wahyu Allah.

\section{Dafar Pustaka}

Bambang Iriana Djajaatmadja (Penerjemah). 2000. Hak-hak Asasi Manusia dalam Islam. Jakarta: Bumi Aksara.

Bayhaqî, Imâm. t.th. Sunan al-Kubrâ. Beirut: Dâr al-Fikr.

Editor, "Asbab Nuzul: Sejarah Turunnya QS. al-Nisâ' :135" dalam http://www.alislamu.com/4728/ surah-an-nisaa-ayat-102sd-135/ diakses tanggal 4 Juli 2015.

Editor. "Risalah Kitab Tanwîr al-Muqâbas min Tafsîr Ibn "Abbâs" artikel dalam http://rumahkitab.com/all-project-list/tanwiral-muqabas-min-tafsir-ibn-abbas/ diakses 2 Juli 2015.

Famawî, 'Abdul Hay al-. 1977. al-Bidâyah fî alTafsîr al-Maudlû'î. Kairo: al-Hadlarah al'Arâbiyyah.

Hâkim, Imâm al-. t.th. al-Mustadrak. Beirut: Dâr al-Fikr.

Hayyie, Abdul (Penerjemah). 1994. Sebab Turunnya Ayat al-Quran. Jakarta: Gema Insani.

Salim, Abd Muin. 1990. Beberapa Aspek Metodologi Tafsir Al-Quran. Ujung Pandang: LSKI.

Shihab, M. Quraish. 2005. Tafsir Al-Misbah: Pesan dan Keserasian Al Quran: Lentera Hati. Jakarta: Gema Insani Press - 1994. Studi Kritis Tafsir al-Manar; Karya Muhammad 'Abduh dan M. Râsyid Ridlâ. Bandung: Pustaka Hidayah.

Yusup, Deni K. "Prinsip-prinsip Universal Hak Asasi Manusia dalam Hukum Islam" makalah dalam Konferensi Internaional Islam dan Hak Asasi Manusia pada Pusat Studi Islam, Universitas Islam Indonesia (UII), Yogyakarta, November 2012. 